This is the accepted manuscript of the article:

Gyöngyvér Szanyi, Zoltán Gráczer \& Erzsébet Győri:

Macroseismic intensity data of the 22 April 2013 Tenk (Hungary) earthquake.

The final published version of the paper appeared in:

Acta Geodaetica et Geophysica, 2014, Volume 49, Issue 3, pp. 283-294.

Online ISSN: 2213-5820

Publisher's version:

http://dx.doi.org/10.1007/s40328-014-0060-x 


\title{
Macroseismic intensity data of the 22 April 2013 Tenk (Hungary) earthquake
}

\author{
Gyöngyvér Szanyi · Zoltán Gráczer • \\ Erzsébet Győri
}

Received: 23 June 2014/ Accepted: 16 July 2014

\begin{abstract}
On 22 April 2013 an earthquake of magnitude 4.8 occurred near the village of Tenk (Hungary), which was the strongest Hungarian earthquake in the past 28 years. This event was detected by a number of seismological stations, thus it is well documented. Nevertheless, it is still possible to get further data through macroseismic surveys, which cannot be obtained using seismological instruments, but are very useful for the understanding of seismic properties of the affected area.

The studied earthquake was felt in approximately third of the territory of Hungary. The number of incoming macroseismic questionnaires was over eight hundred and damage descriptions for the epicentral area reached almost one thousand. Intensity evaluation was carried out following the European Macroseismic Scale guidelines (Grünthal et al, 1998). Intensities were assigned to 211 places, including 23 districts of Budapest. The earthquake caused non-structural building damages, the epicentral intensity was estimated as VI on the EMS-98 scale and was assigned to three villages: Tenk, Átány and Erdőtelek. The event was widely felt west to the epicentre, but much less observed in the east direction. The asymmetry of the intensity distribution raises questions and requires further investigation.
\end{abstract}

Keywords earthquake $\cdot$ macroseismic intensity $\cdot$ seismicity $\cdot$ Pannonian basin

Gyöngyvér Szanyi

MTA CSFK GGI

1112 Budapest, Meredek u. 18

E-mail: szanyi.gyongyver@csfk.mta.hu

Tel.: +36 12482300

Fax: +361248 2301

Zoltán Gráczer

MTA CSFK GGI

1112 Budapest, Meredek u. 18.

E-mail: graczer.zoltan@csfk.mta.hu

Erzsébet Győri

MTA CSFK GGI

1112 Budapest, Meredek u. 18

E-mail: gyori.erzsebet@csfk.mta.hu 


\section{Introduction}

In 2013, the largest earthquake since the 1985 Berhida event $(M=4.9)$ hit Hungary. It could be felt in the third of the territory of the country, including the capital, Budapest, thus millions of people were affected. The event caused damages worth of approximately 2 million euro (Association of Hungarian Insurance Companies, 2013, press release).

Studying the earthquake impacts on humans, the environment and the caused damages are in the focus of macroseismic investigations (e.g. Cecić and Musson, 2004). Although instrumental data nowadays are widely available, it does not substitute macroseismic surveys, as the latter provide a large amount of data from all the areas where the earthquake was felt. Macroseismic observations in Hungary date back two hundred years, and give fundamental contribution to earthquake seismology even today.

The importance of intensity data in the era of instrumental measurements lies in its versatility, these data are crucial for engineering applications (e.g. studies of ground motion attenuation and site amplification), magnitude estimates of historical earthquakes, and seismic hazard and risk analysis.

Macroseismic evaluation is mostly based on detailed questionnaires filled in by the affected people. However, usually only the assigned intensity values are presented in bulletins or in earthquake catalogs in a simple tabular form. Because of the inherent subjective nature of macroseismic input data and evaluation in our opinion it is important to make the process of intensity estimation transparent in case of significant events.

The aim of this paper is to describe the process of assigning intensity values to the 4.8 magnitude earthquake that occurred in Hungary on 22 April 2013 at 22:28 GMT (23 April 2013, 00:28 CET) and evaluate the determined intensity distribution.

\section{Geological setting}

The Pannonian basin is a backarc basin whose formation started in the Early Miocene due to the Europe-Africa convergence (Royden et al, 1982; Ratschbacher et al, 1991; Horváth, 1993; Horváth and Cloetingh, 1996). Subduction of the European foreland and associated rollback of the subducted slab caused lithospheric extension and asthenospheric updoming during the Middle Miocene while discrete basins opened up due to the extension (Royden et al, 1982; Royden, 1988; Horváth, 1993; Bada et al, 2001; Horváth, 2007). In the Late Miocene the asthenospheric dome cooled which led to the subsidence of the whole basin system (Horváth and Cloetingh, 1996; Horváth, 2007). In the latest Pliocene and Quaternary the movement of the Adriatic microplate led to the end of the subsidence and to the inversion of the Pannonian basin (Horváth, 1995; Horváth, 2007; Bada et al, 2007b).

Due to the extension the Pannonian basin can be described with thin lithosphere (Horváth, 1993; Grad et al, 2009), shallow Moho discontinuity (Horváth, 1993; Grad et al, 2009) and high surface heat flow (Lenkey, 1999; Lenkey et al, 2002), thus earthquake activity is limited to the crust (Zsíros, 2000; Tóth et al, 2002). Most of the earthquakes occur between 5 and $15 \mathrm{~km}$ depth (Zsíros, 2000). 
The present tectonics of the Pannonian basin is controlled by the continuous push and counterclockwise rotation of the Adriatic microplate. As a result, compressional stress with complex stress pattern prevails in the basin (Bada et al, 2007a,b).

The epicentre of the investigated earthquake is located south to the North Hungarian Mountain Range, in the northern part of the Great Hungarian Plain (Fig. 1). The epicentre lies close to the Mid-Hungarian line which is a WSW-ENE striking tectonic boundary between the northern ALCAPA and the southern Tisza unit. The Mid-Hungarian line acted as a major strike-slip fault zone during the Late Eocene and Early Miocene (Csontos et al, 1992; Csontos and Nagymarosy, 1998).

According to Fodor et al (2005), based on structural analysis, earthquake and GPS data, the south-eastern Pannonian-Carpathian (Tisza) unit is currently moving eastward with respect to the north-eastern block of the ALCAPA unit and this process results in the formation of active transtensional and transpressional shear zones in the region of the Mid-Hungarian line.

\section{Seismicity in the Central Pannonian region}

Hungary is a country with moderate seismicity (Tóth et al, 2002). The most active seismogenic zone is the Berhida-Komárom zone (Fig. 1), where the largest known Hungarian earthquake has occurred in 1763 with a magnitude of 6.1 (Zsíros, 2004). Its epicentral intensity was IX degree on the EMS scale. During this earthquake approximately third of the city of Komárom was destroyed.

In 1810, a 5.4 magnitude earthquake hit near Mór $\left(\mathrm{I}_{0}=\mathrm{VIII}\right)$, a city south of Komárom (Kitaibel and Tomtsányi, 1814; Zsíros, 2000, 2004). This event was the first thoroughly studied Hungarian earthquake (Réthly, 1910). The book of Kitaibel and Tomtsányi (1814) contained the first map presenting earthquake damages and scientific conclusions such as the directions of seismic wave impacts.

In 1985, the beforementioned 4.9 magnitude earthquake $\left(\mathrm{I}_{0}=\mathrm{VII}\right)$ occurred near Berhida (Tóth et al, 1989), in the southern part of the Komárom-Berhida seismogenic zone.

In the proximity of our investigated earthquake there are three seismogenic zones (see Fig. 1): the first one related to Kecskemét, a city in the Great Hungarian Plain. The largest known earthquake in this zone with magnitude 5.6 occurred in 1911 near Kecskemét. The second zone is located in northern Hungary, where a 5.2 magnitude event happened in 1926 near Eger. The third one is associated with the Jászság region. At the eastern part of it, a 4.9 magnitude earthquake occurred in 1868 near Jászberény (Zsíros, 2000).

In the Central Pannonian region NE-SW trending horizontal maximum stress axes are dominant (Bada et al, 2007a,b). The stress is released mainly in aseismic manner, only around $16 \%$ of it is released by earthquakes (Bus et al, 2009). Focal mechanisms of the earthquakes indicate mainly the combination of strike slip and thrust faulting, without considerable presence of normal faulting earthquakes (Gerner et al, 1999). 


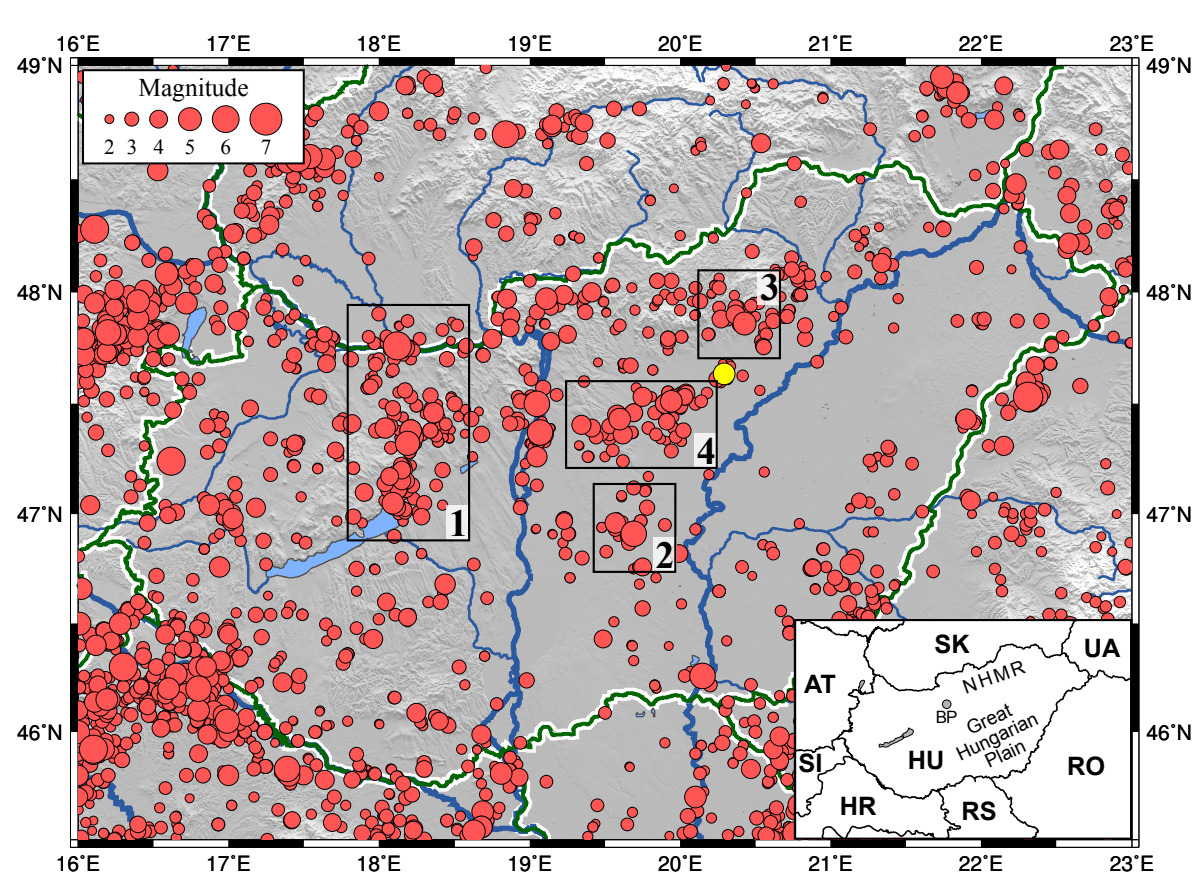

Fig. 1 Seismicity of Hungary and its surroundings. The red circles show the epicentres of the known earthquakes between 456 and 2013 with a magnitude value $\mathrm{M} \geq 2$. The diameter of the circles is proportional to the magnitude. Rectangles mark the most active seismogenic zones in the central Pannonian region described in the text: 1-Komárom-Berhida, 2-Kecskemét, 3-Eger, 4-Jászság. The epicentre of the 22 April 2013 earthquake is indicated by a yellow circle. Inset shows the neighbouring countries and topographic features mentioned in the text: AT-Austria, HR-Croatia, RO-Romania, RS-Serbia, SK-Slovakia, SI-Slovenia, UA-Ukraine, NHMR-North Hungarian Mountain Range and BP-Budapest.

\section{The 22 April 2013 earthquake at Tenk}

At 22 April 2013, 22:28 GMT (23 April, 00:28 at CET local time) an earthquake of 4.8 magnitude occurred near Tenk (Gráczer et al, 2014).

The epicentre of the event was located at the coordinates $47.634 \mathrm{~N}, 20.293 \mathrm{E}$, approximately $100 \mathrm{~km}$ from Budapest, the capital of Hungary. Hypocentre depth was estimated as $10 \mathrm{~km}$. The focal mechanism shows a NW-SE trending thrust fault (Gráczer et al, 2014).

Earlier in 2013, on 16 February, a smaller earthquake of magnitude 3.6 occurred near the city of Heves (followed by a 2.5 magnitude aftershock on the next day). Its epicentre was $4 \mathrm{~km}$ from the epicentre of the $\mathrm{M}=4.8$ earthquake on 22 April. Following the definition of Zsíros (2000), the earthquake that occurred on 16 February, cannot be considered as a foreshock, but as an independent event. Aside from the above mentioned earthquake on 16 February 2013 and its aftershock on the next day, there is no previous record of earthquakes in $18 \mathrm{~km}$ radius of the epicentre of the studied event.

After the main shock, a temporary seismological station was deployed in Tenk and worked from 24 April to 11 September. As a result, 28 aftershocks (Gráczer 


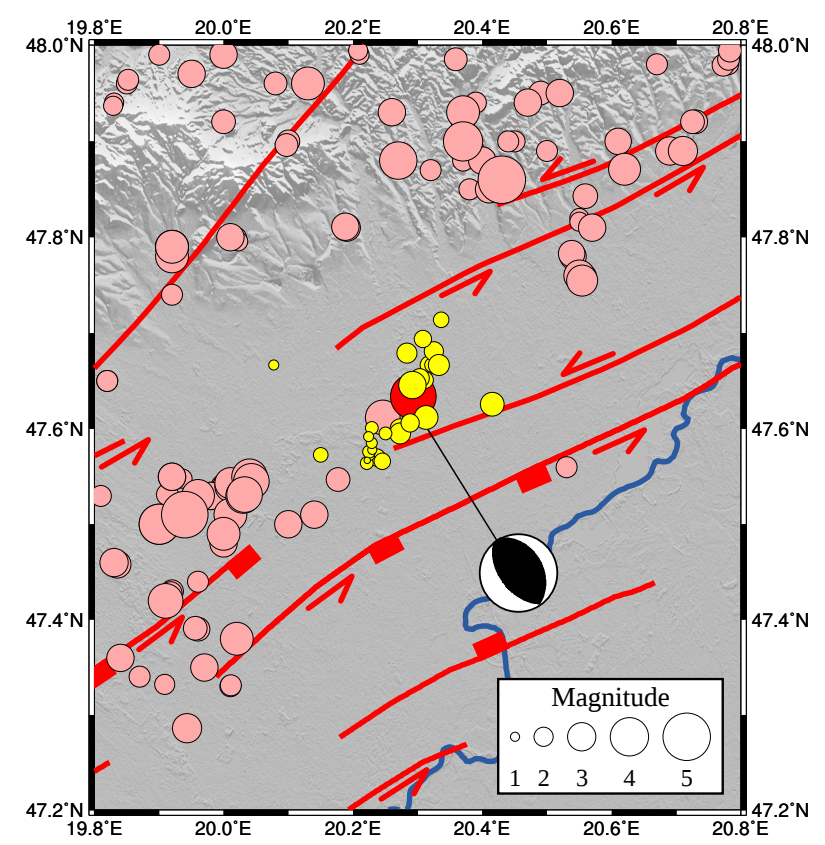

Fig. 2 Seismicity near the 22 April 2013 earthquake epicentre. The main shock is marked by a red circle and the aftershocks by yellow circles. Pink circles indicate earthquakes before 22 April 2013. The diameter of the circles is proportional to the magnitude. The beachball shows the focal mechanism of the main shock (strike: $142^{\circ}$, dip: $53^{\circ}$, rake: $84^{\circ}$ ). Red lines represent the known neotectonic (active) structures according to Horváth et al (2006): square-normal fault, arrow-strike-slip fault.

et al, 2014) were detected (Fig. 2) with magnitudes between 0.7 and 2.9, eight of them were felt by the public (Table 1).

Table 1 Parametres of the 22 April 2013 Tenk earthquake and its felt aftershocks, where $M$ is the local magnitude of the events, $N$ is the number of the received macroseismic questionnaires, $I_{0}$ is the epicentral intensity and locality is the nearest settlement to the instrumental epicentre.

\begin{tabular}{lcccccl}
\hline Date & Time & $\begin{array}{c}\text { Depth } \\
(\mathbf{k m})\end{array}$ & $\mathbf{M}$ & $\mathbf{N}$ & $\mathbf{I}_{0}$ & Locality \\
\hline $22 / 04 / 2013$ & $22: 28$ & 10.0 & 4.8 & 825 & VI & Tenk \\
$24 / 04 / 2013$ & $03: 39$ & 1.0 & 2.5 & 1 & II-III & Heves \\
$28 / 04 / 2013$ & $07: 01$ & 7.7 & 1.5 & 2 & III & Jászszentandrás \\
$08 / 05 / 2013$ & $20: 49$ & 1.3 & 1.7 & 1 & II & Jászszentandrás \\
$18 / 05 / 2013$ & $20: 34$ & 10.0 & 2.9 & 24 & IV-V & Heves \\
$24 / 05 / 2013$ & $18: 54$ & 4.3 & 1.8 & 8 & IV & Erdőtelek \\
$03 / 06 / 2013$ & $21: 23$ & 0.8 & 2.2 & 4 & III-IV & Tenk \\
$11 / 07 / 2013$ & $06: 10$ & 8.1 & 1.9 & 5 & III-IV & Heves \\
$07 / 08 / 2013$ & $08: 01$ & 6.1 & 2.5 & 9 & IV & Tenk \\
\hline
\end{tabular}




\section{Collection of macroseismic data in Hungary}

The MTA Kövesligethy Radó Seismological Observatory collects macroseismic questionnaires (MQs) in different ways. In the past decades a paper questionnaire (e.g. Zsíros et al, 1990) was sent to the councils of the affected settlements. Since 2011, the main datasource has become the online version of the previously used paper questionnaire published at the Observatory's webpage (http://www.seismology.hu). In case of a felt earthquake, we inform the public on the earthquake parameters via our website and facebook page (http://www.facebook.com/krszo), at the same time asking them to fill in the online questionnaire. We also collect data through e-mail, asking local authorities to fill in the online questionnaire or send their remarks by e-mail.

The questionnaire has 30 questions regarding the effect of the earthquake on humans and the environment, and another 30 questions about building damages. Most of the questions have several answer options. The MQ is designed to cover every intensity degree for the EMS-98 intensity scale (Grünthal et al, 1998). Intensity estimation for the Tenk earthquake has been carried out based on the scale degree descriptions in Grünthal et al (1998).

\section{Macroseismic observations of the 22 April 2013 Tenk earthquake}

The epicentre of the studied event is located at the northern part of the Great Hungarian Plain (Fig. 1 and 2). It is surrounded by small settlements with the following population: Tenk-1200, Átány-1500, Erdőtelek-3300, Heves-10900 inhabitants (KSH, 2013). The buildings are mainly made of brick and adobe, which are chategorized as type A and B in the EMS-98 scale (Grünthal et al, 1998).

Using social media to collect macroseismic questionnaires (MQs) had a great effect on the amount of the received data. After the earthquake, it was possible to communicate with the affected people and in some cases we directly asked them to fill in our online questionnaire.

The National Directorate General for Disaster Management also provided data of 996 damaged buildings from the three most affected villages: Tenk, Erdőtelek and Átány. Their data contained the addresses, function of the buildings (e.g. residential building, warehouse) and the type of injuries for each building: cracks, chimney damage, plaster injury, damage of the roof and other type of damage. We also received 335 MQs from the European-Mediterranean Seismological Centre (EMSC).

During data processing the spatial asymmetry of the incoming MQs was conspicuous, there were much less questionnaires from the east than from the west of the epicentre. Settlements are located sparsely eastward, this could be one reason of limited data from this area. On the other hand, it was also possible, that the event was felt less and did not cause much damage east to the epicentre. To decide which scenario is true, we called the mayors of the surrounding settlements and asked about their and the residents' experiences about the earthquake and whether there has been reported any building damages. Based on these conversations intensities were assigned to 11 settlements.

In summary, 825 questionnaires were filled in (373 from Budapest) and 996 damage descriptions were received from the National Directorate General for Dis- 


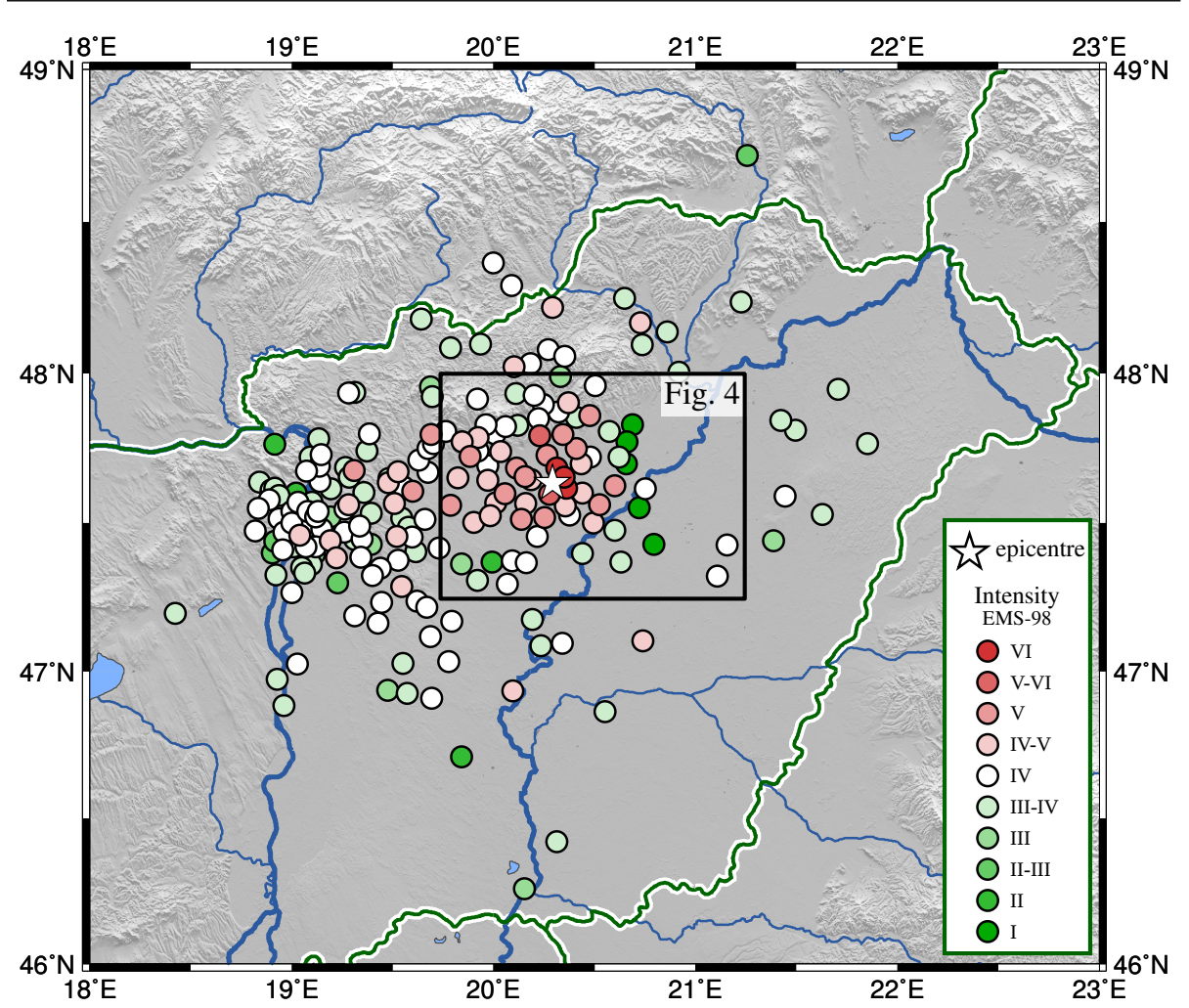

Fig. 3 Intensity map of the 22 April 2013 earthquake. The instrumental epicentre is marked by white star. Intensity distribution in the proximity of the epicentre is shown in Fig. 4.

aster Management and intensities were assigned to 211 settlements (including 23 districts of Budapest). Detailed list of the intensity values can be found in Gráczer et al (2014).

The maximum intensity value (VI) was assigned to 3 villages: Tenk, Átány and Erdőtelek (Fig. 3 and 4). In these settlements the earthquake was accompanied by strong sound. Most of the people were awakened, frightened and many run outdoors, but no injuries were reported. Animals became uneasy and scared. Hanging pictures swang, turned and fall down, doors shut, china and glasses broke and in a few instances window panes broke as well. The buildings were shaking, many small objects overturned, many light furniture shifted, heavy furniture often were shaken, sometimes even shifted, rarely overturned.

To illustrate the experiences of the residents we present some quotations from the facebook comments and the remarks field of our MQs:

'Everything was moving in the house. A lot of pots, ceramics and bottles were broken. We were really scared!' / a resident of Tenk /

'It was like we were flying for a few moments and everything was shaking. The roaring were so strong that the animals jolted awake.' /a resident of Tenk/ 


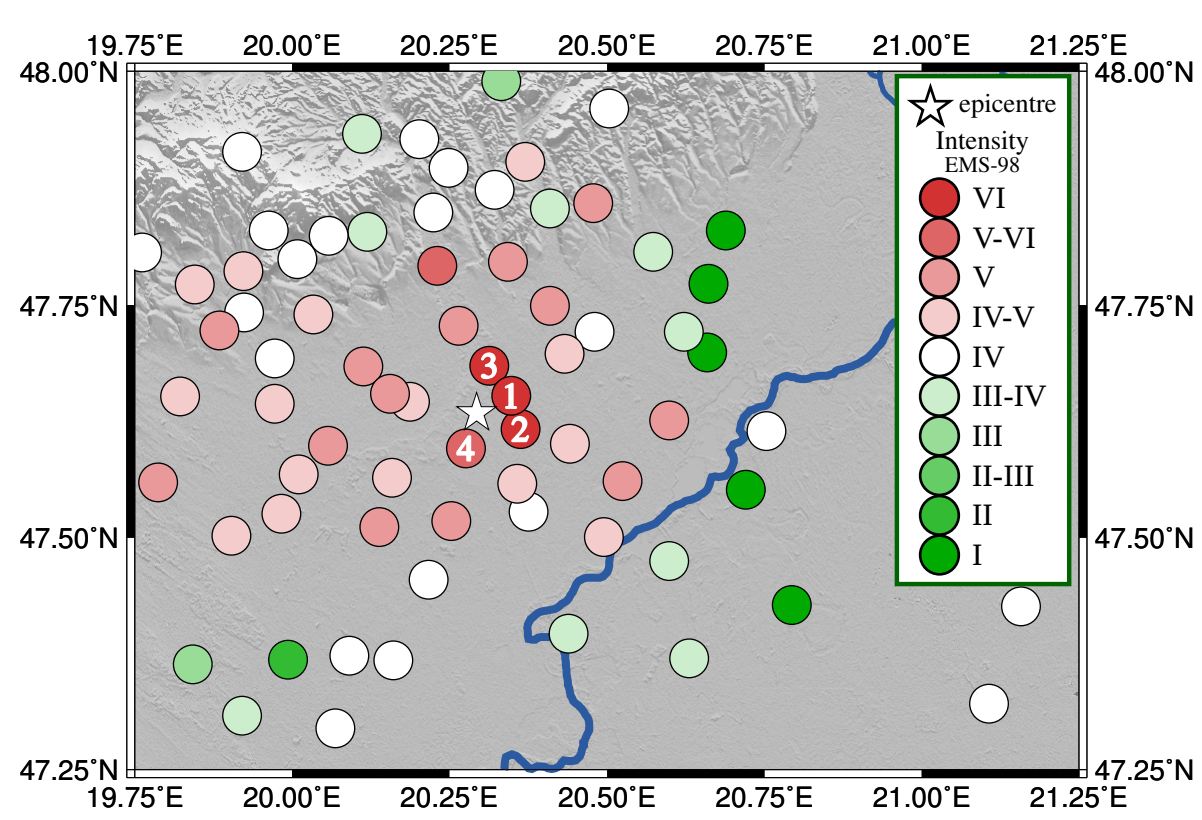

Fig. 4 Intensity map of the 22 April 2013 earthquake in the surroundings of the epicentre. The instrumental epicentre is marked by white star. Most affected settlements: 1-Tenk, 2-Átány, 3-Erdőtelek, 4-Heves.

'I awoke to a loud rumble, the whole house was shaking and the glasses were rattling. Objects fell off the cupboard and smashed. I had a fear of death!!' /a resident of Átány/

'There came a loud rumble from the ground, then the bed moved and the glasses were rattling in the cupboard. The alarms turned on and all the neighbours around us were in the yards and the streets. The dogs were barking, the fright was big enough.' /a resident of Heves/

The buildings suffered non-structural damages: cracks in walls, in the ceiling, at doors and windows, fall of pieces of plaster, loose of bricks in chimneys or partial collapse of them. Tiles fell off the roof in some instances. According to the data of the National Directorate General for Disaster Management Tenk suffered the most serious damages, $79 \%$ of the buildings were damaged, $41 \%$ of all buildings had chimney damage, but structural damage of any building was not reported. In Átány $63 \%$ of the buildings were damaged, $18 \%$ suffered chimney damage. In Erdőtelek $19 \%$ of the buildings were damaged and chimney damage was $6 \%$.

Considerable damage was reported from the city of Heves as well and intensity of V-VI was assigned. The effect of the earthquake on humans was similar to that of Tenk, Átány and Erdőtelek. Most of the people awakened, were frightened and many run outdoors. They experienced strong shaking of the whole building and some of them lost their balance. Animals were frightened as well. Effect on the environment and damage to the buildings were less compared to the above mentioned villages. China clattered together and in a few cases broke. A few of the hanging pictures fall and some of the smaller objects overturned. Doors shut in 

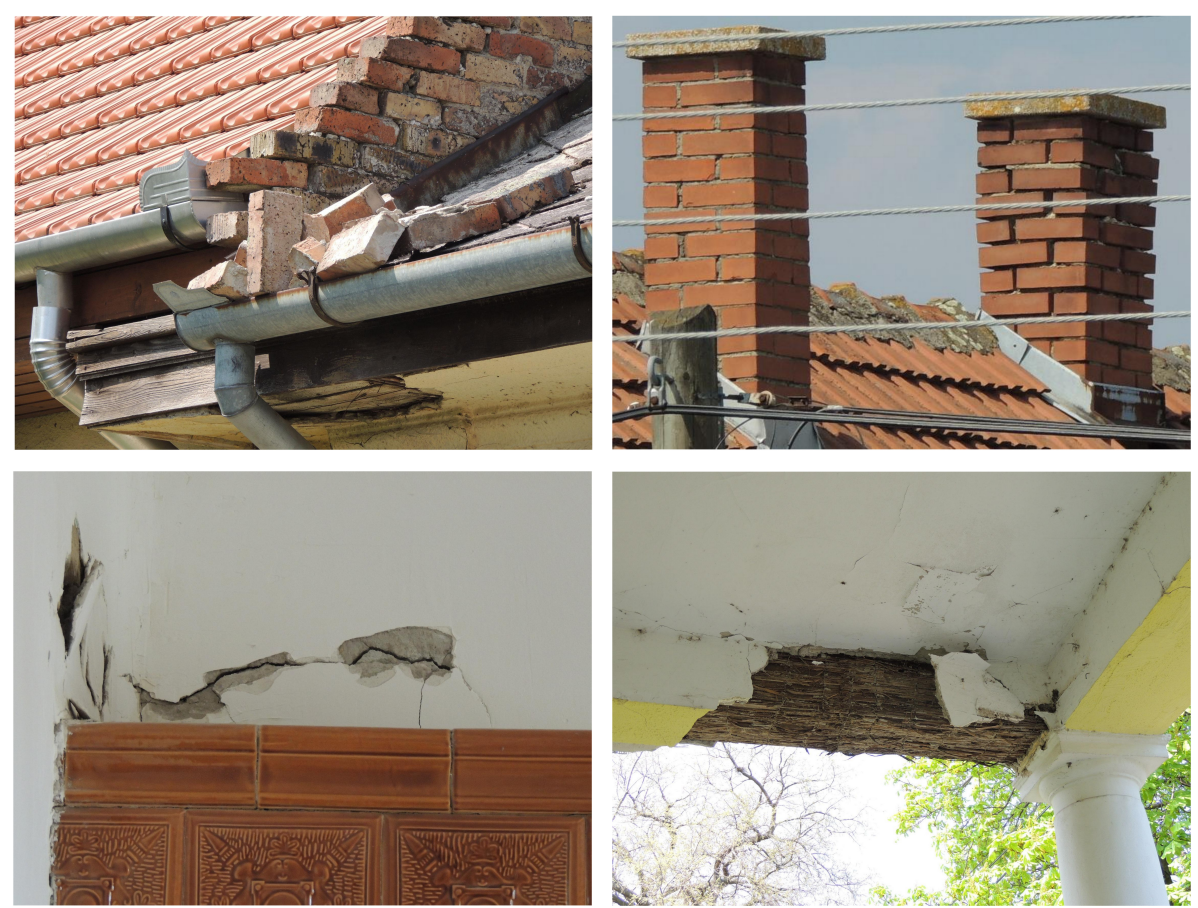

Fig. 5 Characteristic building damages in Tenk. (Photos: Erzsébet Győri)

a few instances. Light furniture often moved but were not shifted. Heavy furniture was visibly shaking in many cases. Damage of adobe, brick and slag buildings were reported: mainly cracks in plaster and in the walls. Chimneys were damaged in a few instances and in a few cases rooftiles fell.

Occasionally the completed MQs were highly controversial, which made intensity estimation rather difficult, especially when only a few MQs were received from a given settlement. In some cases, they have simultaneously reported great fright and many people running outdoors, but with almost no effect on the environment, such as the lack of china clattering and shifting or overturning small objects. In these cases, intensity IV-V was assigned. Intensity V was assigned only to those settlements (Apc, Atkár, Erdőkertes, Füzesabony, Jászapáti, Jászivány, Kál, Kerecsend, Nagyfüged, Novaj, Pusztamonostor, Tarnaméra, Tiszaörs, Tura and Ujlörincfalva), where the reported effect on people, environment and damages corresponded to intensity V in the Grünthal et al (1998) scale description. The earthquake caused damage up to $100 \mathrm{~km}$ epicentral distance (Fig. 3), hairlinecracks in plaster were reported from several points of Budapest, mainly from upper floors of storey houses.

Intensity was estimated as IV-V where small building damages were reported, but only a few people felt the quake, and observers reported moderate vibration and a slight trembling or swaying of the building. The same intensity was assigned, when the earthquake was felt indoors by many people, china and glasses clattered 
together and many small objects shifted and fell down, window panes rattled and large furniture moved but building damage was not reported.

The earthquake was felt in a large area of Hungary. Questionnaires were filled in mainly from those territories, where many people felt the earthquake and some of them awakened to the event, thus intensity III, III-IV and IV are the most common assigned values (Fig. 3).

The resulted intensity distribution is asymmetric, the earthquake was widely felt westward, but it was much less observed east of the epicentre. The area of the highest seismic intensities ( $\mathrm{V}$ or more) is elliptical in shape elongated in the $\mathrm{E}-\mathrm{W}$ direction (Fig. 3).

\section{Intensity attenuation}

Zsíros $(1996,2000)$ has given the absorption coefficients for different focal depth ranges based on the Kövesligethy-formula and a relationship between the magnitude, epicentral intensity and focal depth for the earthquakes of the Pannonian basin. Using the focal parameters of the Tenk earthquake, we computed the respective intensity attenuation curve. Comparing the assigned intensities with the attenuation curve, it can be seen that the experienced epicentral intensity is one scale degree less than the predicted value and the attenuation rate is much smaller (Fig. 6).

As it was described in Section 6 we applied targeted questioning for filling up the apparent holes in the intensity distribution. The independent data providers of Borsodivánka, Kunmadaras, Mezőkeresztes, Szentistván and Tiszaszőlős unanimously claimed that the earthquake was not felt in their settlements. It means that in these places, 30 to $45 \mathrm{~km}$ to the east of the epicentre, the earthquake was barely or not at all felt, while westward at the same distance intensity III to $\mathrm{V}$ was found to be common.

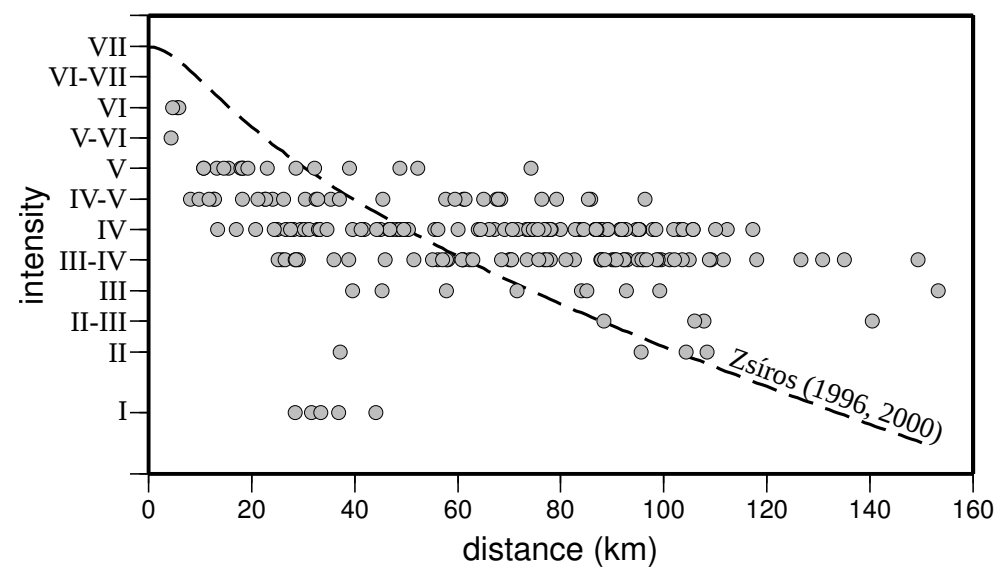

Fig. 6 Intensity values of the 22 April 2013 Tenk earthquake as function of distance and the predicted intensity attenuation based on the formulas of Zsíros (1996, 2000). 


\section{Conclusions}

The 22 April 2013 Tenk earthquake was the strongest one in Hungary in the past 28 years and generated significant public response and high media coverage. Due to the great interest a large number of questionnaires and damage reports have been obtained. The earthquake was felt in approximately third of the territory of Hungary.

Based on the macroseismic questionnaires and damage reports we determined 211 intensity values. The maximum macroseismic intensity was assigned to three villages in the proximity of the epicentre, with intensities of VI at the EMS-98 scale. The area of the highest seismic intensities ( $\mathrm{V}$ or more) is elliptical in shape elongated in the E-W direction (Fig. 3). The intensity distribution of the event is very asymmetric, it was widely felt west to the epicentre, but it was much less observed in the east direction.

It can be clearly seen from Fig. 6, that the intensity attenuation curve based on the formulas of Zsíros (1996, 2000) differs significantly from the experienced intensity attenuation. The question arises whether using modern regression techniques can increase the accuracy of the estimations or not. To answer this question, research is underway.

The presented macroseismic study provided a valuable dataset of intensities and hopefully contribute to the determination of better fitting intensity attenuation curves and to studies of seismic hazard assessment.

Further research is required to ascertain whether the asymmetry can be explained by the radiation field pattern (e.g. Gosar, 2014) or it occurs as a consequence of local site effects. The probability of the latter explanation is reduced by the fact, that both eastward and westward of the epicentre, the sedimentary environment of the Great Hungarian Plain is present and significant geological change cannot be observed.

Acknowledgements The authors are indebted to the National Directorate General for Disaster Management, especially Lt. Col. Zsolt Szarka for their kind help in damage data acquisition. We would like to thank Tamás Szopkó, mayor of Tenk, for his help. We are very grateful to the European-Mediterranean Seismological Centre for the provided macroseismic questionnaires.

This study was supported by the TÁMOP-4.2.2.C-11/1/KONV-2012-0015 (Earth-system) project sponsored by the EU and European Social Foundation and the Hungarian Scientific Research Fund under Grant OTKA K105399.

Maps were generated with the Generic Mapping Tools (GMT) data processing and display software package (Wessel and Smith, 1991, 1998).

\section{References}

Bada G, Horváth F, Cloetingh SAPL, Coblentz DD, Tóth T (2001) Role of topography-induced gravitational stresses in basin inversion: The case study of the Pannonian basin. Tectonics 20:343-363

Bada G, Dövényi P, Horváth F, Szafián P, Windhoffer G (2007a) Jelenkori feszültségtér a Pannon-medencében és alpi-dinári-kárpáti környezetében. Földtani Közlöny 137(3):327-359 
Bada G, Horváth F, Dövényi P, Szafián P, Windhoffer G, Cloetingh SAPL (2007b) Present-day stress field and tectonic inversion in the Pannonian basin. Global and Planetary Change 58(1):165-180

Bus Z, Grenerczy Gy, Tóth L, Mónus P (2009) Active crustal deformation in two seismogenic zones of the Pannonian region-GPS versus seismological observations. Tectonophysics 474(1):343-352

Cecić I, Musson R (2004) Macroseismic surveys in theory and practice. Natural Hazards 31(1):39-61

Csontos L, Nagymarosy A (1998) The Mid-Hungarian line: a zone of repeated tectonic inversions. Tectonophysics 297(1):51-71

Csontos L, Nagymarosy A, Horváth F, Kovac M (1992) Tertiary evolution of the Intra-Carpathian area: a model. Tectonophysics 208(1):221-241

Fodor L, Bada G, Csillag G, Horváth E, Ruszkiczay-Rüdiger Zs, Palotás K, Síkhegyi F, Timár G, Cloetingh SAPL, Horváth F (2005) An outline of neotectonic structures and morphotectonics of the western and central Pannonian Basin. Tectonophysics 410(1):15-41

Gerner P, Bada G, Dövényi P, Müller B, Onescu MC, Cloetingh SAPL, Horváth F (1999) Recent tectonic stress and crustal deformation in and around the Pannonian basin: data and models. In: Durand B, Jolivet L, Horváth F, Séranne M (eds) The Mediterranean basins: Tertiary extension within the Alpine orogen, Geol. Soc. London Spec. Publ., vol 156, pp 269-294

Gosar A (2014) Analysis of the Impact of Fault Mechanism Radiation Patterns on Macroseismic Fields in the Epicentral Area of 1998 and 2004 Krn Mountains Earthquakes (NW Slovenia). The Scientific World Journal

Gráczer Z, Czanik Cs, Czifra T, Győri E, Kiszely M, Mónus P, Süle B, Szanyi Gy, Tóth L, Varga P, Wesztergom V, Wéber Z (2014) Hungarian National Seismological Bulletin 2013. Kövesligethy Radó Seismological Observatory, Budapest, (in preparation)

Grad M, Tiira T, ESC Working Group (2009) The Moho depth map of the European Plate. Geophysical Journal International 176(1):279-292

Grünthal G, Musson R, Schwarz J, Stucchi M (1998) European Macroseismic Scale 1998 (EMS-98), Centre Européen de Géodynamique et de Séismologie

Horváth F (1993) Towards a mechanical model for the formation of the Pannonian basin. Tectonophysics 226(1):333-357

Horváth F (1995) Phases of compression during the evolution of the Pannonian Basin and its bearing on hydrocarbon exploration. Marine and Petroleum Geology 12(8):837-844

Horváth F (2007) A Pannon-medence geodinamikája - Eszmetörténeti tanulmány és geofizikai szintézis. ELTE Földrajz- és Földtudományi Intézet, Geofizikai Tanszék, Budapest

Horváth F, Cloetingh SAPL (1996) Stress-induced late-stage subsidence anomalies in the Pannonian basin. Tectonophysics 266(1):287-300

Horváth F, Bada G, Windhoffer G, Csontos L, Dombrádi E, Dövényi P, Fodor L, Grenerczy Gy, Síkhegyi F, Szafián P, Székely B, Timár G, Tóth L, Tóth T (2006) Atlas of the present-day geodynamics of the Pannonian basin: Euroconform maps with explanatory text. Magyar Geofizika 47:133-137

Kitaibel P, Tomtsányi Á (1814) Dissertatio de terrae motu in genere, ac in specie Mórensi anno 1810. die 14. Januarii orto. Typis Regiae Universitatis Hungaricae, Budae, Reprint: Akadémiai Kiadó, Budapest, Hungary, 1960. 
KSH (2013) Gazetteer of Hungary 1st January, 2013. Központi Statisztikai Hivatal, Budapest

Lenkey L (1999) Geothermics of the Pannonian basin and its bearing on the tectonics of basin evolution. PhD thesis, Vrije Universiteit, Amsterdam, The Netherlands.

Lenkey L, Dövényi P, Horváth F, Cloetingh SAPL (2002) Geothermics of the Pannonian basin and its bearing on the neotectonics. In: Cloetingh SAPL, Horváth F, Bada G, Lankreijer AC (eds) Neotectonics and surface processes: the Pannonian basin and Alpine/Carpathian system, EGU Stephan Mueller Special Publication Series, vol 3, pp 29-40

Ratschbacher L, Merle O, Davy P, Cobbold P (1991) Lateral extrusion in the Eastern Alps, part 1: boundary conditions and experiments scaled for gravity. Tectonics 10(2):245-256

Royden L (1988) Late Cenozoic tectonics of the Pannonian basin system. In: Royden L, Horváth F (eds) The Pannonian Basin: A Study in Basin Evolution. Memoir, American Association of Petroleum Geologists, vol 45, pp 27-48

Royden LH, Horváth F, Burchfiel B (1982) Transform faulting, extension, and subduction in the Carpathian Pannonian region. Geological Society of America Bulletin 93(8):717-725

Réthly A (1910) Az 1810 januárius 14-iki móri földrengés. Földtani Közlöny 40(34):133-155

Tóth L, Mónus P, Zsíros T (1989) The Berhida (Hungary) earthquake of 1985. Gerlands Beitr Geophysik 98(4):312-321

Tóth L, Mónus P, Zsíros T, Kiszely M (2002) Seismicity in the Pannonian Region earthquake data. In: Cloetingh SAPL, Horváth F, Bada G, Lankreijer AC (eds) Neotectonics and surface processes: the Pannonian basin and Alpine/Carpathian system, EGU Stephan Mueller Special Publication Series, vol 3, pp 9-28

Wessel P, Smith W (1998) New, improved version of Generic Mapping Tools released. Eos Transactions 79:579-579

Wessel P, Smith WH (1991) Free software helps map and display data. EOS Transactions 72:441-446

Zsíros T (1996) Macroseismic focal depth and intensity attenuation in the Carpathian region. Acta Geodaetica et Geophysica Hungarica 31(1-2):115-125

Zsíros T (2000) A Kárpát-medence szeizmicitása és földrengés veszélyessége: Magyar földrengés katalógus (456-1995). MTA GGKI

Zsíros T (2004) Seismicity of Komárom-Mór area. Acta Geodaetica et Geophysica Hungarica 39(1):121-132

Zsíros T, Mónus P, Tóth L (1990) Computer estimation of intensities: The 1985 Berhida, Hungary, earthquake. Pure and Applied Geophysics 132(3):533-543 